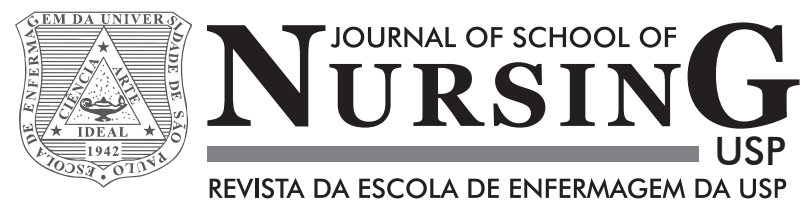

\title{
Taking care of the newborn dying and their families: Nurses' experiences of neonatal intensive care
}

\author{
Cuidando do neonato que está morrendo e sua família: vivências \\ do enfermeiro de terapia intensiva neonatal \\ El cuidado de los moribundos recién nacidos y sus familias: las \\ experiencias de enfermeras de cuidados intensivos neonatales
}

Fabiane de Amorim Almeida ${ }^{1}$, Mariana Salim de Moraes ${ }^{2}$, Mariana Lucas da Rocha Cunha ${ }^{3}$

${ }^{1,3}$ Faculdade Israelita de Ciências da Saúde Albert Einstein (FICSAE). São Paulo, SP, Brazil.

${ }^{2}$ Clínica de Imunização Pediátrica -

Departamento Materno Infantil. Hospital Israelita Albert Einstein. São Paulo, SP, Brazil.

\section{ABSTRACT}

Objectives: To understand the experiences of nurses when caring for dying newborns and their families in the NICU; and redeem their perceptions about acting before the death and grieving process. Methods: A descriptive exploratory study with a qualitative approach, developed with nine nurses at the ICU of a hospital in São Paulo (SP), Brazil. Data was collected through semi-structured interviews and analyzed using the Collective Subject Discourse (CSD). Results: Caring for newborns who are dying and their families is very difficult for nurses, due to the intense involvement. They seek strategies to deal with the situation and, before the newborn's death, despite the suffering, express the feeling of accomplishment. Final considerations: Facing death and grief triggers mechanisms that emerge life references, coming across painful issues. Learning to deal with these questions is a daily challenge for nurses of the NICU.

\section{DESCRIPTORS}

Death; Nursing Care; Neonatal Intensive Care Units. 


\section{INTRODUCTION}

The Neonatal Intensive Care Unit (NICU) is a specialized environment in the care of newborns at term or preterm in life-threatening conditions that require continuous monitoring and/or specific therapies. In this unit, healthcare professionals addresses all their efforts to care for seriously ill newborns and their needs, as well as the newborns' family needs ${ }^{(1-2)}$.

Listening to the fears and concerns of the family before informing them about the routine of the unit, equipment and the care provided to their child is essential to build a relationship of trust between the family and the healthcare team, reducing anxieties and fears ${ }^{(2-3)}$.

Due to this closer relationship with the newborn and his/her family, professionals in the NICU, in particular the nursing staff, deal with difficult emotional situations. The fragility and suffering of an extremely premature baby, in life-threatening conditions, and feelings of anxiety and insecurity of family members are constant in their daily work ${ }^{(4)}$.

In addition, complications in the newborn's clinical evolution are frequent and they require not only technical skills, specific and updated knowledge, but also agility and sensitivity, causing great physical and emotional stress in these professionals ${ }^{(4)}$.

Being part of the process of death and grief in the NICU is particularly challenging for nurses who may present feelings of failure in their role of health promotion. This is partially due to the way they face the process of dying, which is mainly related to our culture, as well as personal and professional experiences.

Currently, death is no longer seen as a natural process, as it did in ancient societies, when the ill person would die at home with his/her family. With the advancement of medicine and social changes, death is no longer part of the daily lives of people, starting to occur more and more often in hospital and, usually in intensive care units (ICUs) ${ }^{(5)}$.

The technological resources available today lead to prolongation of the dying process and hence the additional suffering for patients and their families. The feeling is that death can be preventable and professionals feel obliged to make every effort to extend the life of the patient ${ }^{(5)}$.

Given this scenario, we can see an even greater difficulty on the part of society to accept death of children and young people, especially newborns. In the case of a stillbirth or a newborn who dies within a few hours or days after birth, this loss may seem like a tragedy, because throughout pregnancy, expectations and dreams of a perfect son/daughter were created ${ }^{(6)}$.

When a newborn dies, family members need to complete their bond with the baby and gradually distance themselves from him/her, so they can focus their attention on their needs and family life, progressing in the grieving process $^{(6)}$.

The experience of the authors of this study in living together the suffering of the families who lost newborns in their career led them to investigate how nurses deal with the grief of these families, leading them to reflect on some questions: how do nurses feel when dealing with families of newborns admitted to the NICU who are living the grief process? How do these nurses deal with this situation so that they can interact effectively with families and meet their needs at the moment they mostly need? What is the impact of these experiences in their personal lives?

Thus, the study proposes understanding the experiences of nurses when caring for newborns who are dying and their families in the NICU and rescue the perception of these professionals regarding their performance experienced before death and the grief process.

\section{METHOD}

This is an exploratory descriptive study of qualitative approach, developed in a NICU with nurses from a private hospital in São Paulo, who agreed to participate. Professionals who were away from their activities because of vacation or leave during the period of data collection were excluded.

Because it is a qualitative research, the number of participants was defined during the data collection, which was concluded when researchers could understand the experience lived by nurses.

The sample consisted of nine nurses, all female, with more than three years of completion of their undergraduate degree (55.6\%) and working in the NICU (66.7\%), all nurses were experts in neonatal and/or pediatric area.

Data were collected in the second half of 2011 through semi-structured interviews, which were recorded, so that they could be literally transcribed. After explaining about the research and their participation, the researcher scheduled the interview, after that, the signature of the consent form was obtained.

The interview was conducted using a script containing information about the participants and two guiding questions related to nurses' experiences in relation to the care of critically ill dying newborns and their families.

Data collection started after the project was approved by the Research Ethics Committee (CAAE $n^{\circ}$ 0066.0.028.000-11) and authorized by the unit manager where data were collected, the researchers were committed to use data collected only for this research.

For data analysis, we used the "Collective Subject Discourse" (CSD) method, and tabulation and organization technique of qualitative data that has as its basis, the theory of Social Representation ${ }^{(7)}$.

In order to prepare the CSD, individual discourses, in their raw state, are decomposed by selecting their main ideas, key expressions and anchorages, which allow the construction of categories. Through this process, we hope to achieve the discursive reconstitution of the social representation, as the discourse of all subjects become the discourse of one $\mathrm{e}^{(7-8)}$.

\section{RESULTS}

Nurses' discourse allowed us to identify five CSDs, which are presented below. 


\section{IT IS A DIFFICULT TIME FOR THE NURSE}

The reports showed that the death of the newborn is always a very difficult time for professionals as they establish a strong bond with the infant and his/her family. We also emphasize that it is always more difficult to accept the death of a newborn than an adult or elderly.

"There are situations that are a little bit more diffcult... such as these situations of death. It is a very difficult moment for the whole team, not just to nurses... Also because not everyone has this serenity... We were trained to take care of alive people, not dead people, right. And even more at this age... if they were dying elderly, you accept. I know this is wrong, but I accept that the elderly has already lived, had his life, was happy, got married, had a son. Now, a baby had nothing, okay ... nothing, simply nothing, okay! He did not even have time to have..." (CSD 1)

The nurse begins to experience some of the daily life of that family, knowing their anxieties, fears and intensely participating of their daily routine, at a time of family fragility.

"We end up getting involved, creating a very great bond: family, baby and staff (...) So for us, nurses, who're closest to the family, it is clear that we suffer more than the doctor who, of course, suffers, but it's a different involvement. We're there six hours, every day, until he/she (the baby) dies, right..." (CSD 1).

The nurse also reflects on the quality of life of the newborn that survives because of the risk of significant sequelae, and the impact of this event on the family. Nurses will reflect on their actions and efforts for the survival of the infants, which could generate equally complex consequences for the family if he/she survives.

"Suddenly, you end up doing things, sometimes fearfully heroic things, and perhaps all of that wasn't needed, right (...) Will these actions cause any trouble up ahead? Until what extent should I do it? Just to allow this infant to become what then? Does the family have the right structure to be able to take care of his/her special needs (...) If you think of quality of life as one would imagine of a child ... playing in the street, being happy, doing everything, being healthy and happy... without having to leave someone who will be dependent all their lives... because that's what will happen, right!" (CSD 1)

Nurses wonder to what extent should they invest in maintaining life of seriously ill neonates who do not have a good prognosis, since that decision is not up to the nurse.

"You also question yourself what's best for this infant and for this family. So on one hand you want the infant to go away as well (home). But if you think of the quality of life the infant will have... how much should we keep doing? So that at the end, he or she won't have absolutely no quality of life, right... This is a very common question! And we, nurses, do not have that power to stop here. We may avoid suffering, right..." (CSD 1)

\section{SEEKING STRATEGIES TO FACE SUFFERING.}

The statements show how this experience creates suffering for nurses, especially when they establish a strong bond with the family, and how this loss can interfere with their personal life. Expressing their suffering through crying or praying for the families are some strategies used by professionals facing the situation.

"Saying that I came home and cried for a patient who
died, no. I've cried when I saw the family suffering,
when they're losing the patient... for the suffering of
who's going through that loss. We are not prepared
for this, so we cry a lot... either we cry or we became
sick... You can choose what is best, what is worse for
you... depends on how emotionally stable you are able
to whether or not show your feelings. I have collea-
gues who cry as much or more than the family (...)
So, sometimes, I wonder... I ask for comfort, pray...
I pray for that person who's leaving... to give them
comfort, giving them the best way to leave, but also
to provide comfort to those who stay... That's it. But I
don't usually suffer for several days, that would be too
difficult..." (CSD 2)

For some nurses, there are situations where it is impossible not to get involved with family and suffering is inevitable. At such times, nurses count on the help of other colleagues.

\section{"And in this case, specifically, I suffered quite a lot. I could not really separate it from my personal life. I was mourning for a few days. I suffered so much that when the mother arrived, I asked another nurse to show the newborn to her... because I was not able to show at the time. I was touched..." (CSD 2)}

At other times, however, despite the sadness, the professional can keep their self-control.

"On the other hand, there are other situations where we can separate things well in my mind. You're sad at that time, for what happened... We have connections to family, right. I think that here I can ... out of here, it's different. Especially after you have kids. Even if you are not a mother, you get involved with the child, right... But we, when the time comes, have to do what has to be done and ready, okay? I think the important thing is this. You have to know that the professional is one thing and the personal sphere is another. So I'm not dwelling on that later... not that." (CSD 2)

The working time in the area, repeatedly living these experiences, leads the professional to adopt some attitudes to help them cope better with the situation. However, they never seem to feel fully prepared for the moment the infant dies, sometimes they do not know what to do and what to say to the parents and family.

"It has been a few years since I started working in the NICU, so I think I can separate a little bit. Time of experience helps, because you end up creating defense mechanisms in this regard. So when you see that a child is a bit more serious, who will probably evolve 
into... (death), we already begin to prepare ourselves... But I think it is only after a while... that you learn." (CSD 2)

\section{RECOGNIZING THAT THE TIME IS MUCH MORE DIFFICULT FOR THE FAMILY}

For nurses, caring for a dying newborn is difficult for everyone, however, for the family, the suffering is much greater. We realize the frustration that the family faces before the loss situation at a time of life that is usually marked by celebration and commemoration.

"It is a difficult moment for everyone and I think to
the family is much more (emphasis). The baby, when
he or she is born, everyone celebrates. It is a time of
celebration, not a time of grief, right... Then, sudden-
ly, there isn't much to celebrate... It's weird huh... It's
strange..." (CSD 3)

The following nurse emphasized the importance of the psychologists in the unit to perform emotional support to this family, even before the baby passes away.
"We have a psychologist here in the NICU and she helps in this emotional part, sometimes she helps fa- milies to deal a little better with the whole situation, especially to help the couple in their interpersonal relationship. So what happens is that she follows up those babies that are pre-dead or who have a very bad prognosis..." (CSD 3)

Another fact that emerged in the discourses is when there are twins and one of them has just died. They understand the mother's distance from the NICU and the milk bank as a step in the grieving process that she must confront, so that she can continue to care for the baby who survived.

"They were twins... and one of them died and the other didn't, right ... and in the family you see these mixed feelings, on one hand, with pain, on the other hand, with joy... it is something, you know, strange... Especially because they are talking about the death of their son, which is a very tricky thing in this case, so it took her 2 or 3 days to touch the other baby again, right (...) So she did not come at the milk bank, nothing, buh... She was going through grief, even part of her, right... closing this end of story, right. In the end, it was really nice because she could deal with her other baby... she was able to participate in all his little life... but she needed to go through that moment..." (CSD 3)

\section{Helping the family to faCe DeATH}

Facing the infant's death moment, nurses try to help the family, even if they still do not feel adequately prepared to face the situation. They are concerned to ensure the privacy of the family, meeting their wishes and requirements at the time. They understand that the family needs to experience the grief stages and strive to help them go through them as best they can.
"And at the moment that the baby dies, we always close the curtains, let them talk to the baby for as long as they need... to experience death... to go through the process of acceptance... And we tell them that we're there to whatever they might need, we try to feel what that mother needs at that moment, some of them need to be alone at that moment. It's that moment that it is no use offering your shoulder, no use offering a psychologist, no use, because she does not want it from us, she wants our silence." (CSD 4)

The nurse allows the family to take care of the baby's body, as well as the entry of other family members in the unit, so that they may say goodbye.

"We offer the mother, if she wants to get the baby... they end up bathing, putting clothes on this baby, doing all the emotional part to finish that story. They need closure... every story has a beginning, a middle and they must have an end ... We allow family members to come inside, not only the mother and the father, but other relatives... Grandparents. Sometimes they pray beside the baby, or baptize them... They have to say goodbye, right! I think we should give them whatever time they need... and encourage them, even to cry. Because it is their moment, so they can cry..." (CSD 4)

Promoting a good environment, touching them and being available to hear the family are some more strategies employed by the nurse.

"I think the primary thing is also to give them an environment that will calm them down, touching them. I like touching them: hand, arm ... offering water. Because I think, at these moments, we have to listen, more than talk, you know... Sometimes we do not have much ability to talk about what they need and every family faces death in their own way. So the less you speak, I think it's better for that person to live that, going through that time. But I think we learn it after a while..." (CSD 4)

The nurse believes that professional involvement with parents during hospitalization is essential to help them cope with the loss of the baby. This involvement depends on the interaction established between the nuclear family and the team, the dynamics of each family and also the newborn's length of stay in the unit.
"The involvement usually depends of parents... de- pending on the involvement you have with the child, with family. There are some (parents) that give us space, there are others who are more closed, right... There are those who like to talk... There are others who stay here very little and sometimes end up not having much bond with us. It varies greatly... We create bond depending on the parents, right... Depending on the case, if (the baby) was here for a long time (in the unit), we can approach them better... If it was a very quick stay in the NICU, we end up not being able to do much, right. It makes the difference." (CSD 4) 
The nurse also highlights how much empathy can interfere with her way of bonding with family.

\begin{abstract}
"It depends largely on the empathy I have for the couple, as I relate to them, how I can easily talk to them, if they are distant or not. Because there are couples who do not want us to interfere with anything... they are closed and do not want us to get in the middle of their world. Sometimes we don't feel empathy for that couple... I don't like them, I don't think they are friendly, then, it is much more difficult for me to be sympathetic to them, right! But it's what I say, it depends on the child..." (CSD 4)
\end{abstract}

\section{EXPERIENCING A FEELING OF ACCOMPLISHMENT, DESPITE THE SADNESS FOR THE LOSS OF THE NEWBORN}

Despite all the sadness and moments of anguish experienced by the nurse facing the death of the newborn, there is a sense of accomplishment because they understand that they did everything that was possible for that baby. And when a healthy relationship is established, parents often return some time after death and express their gratitude, reinforcing the feeling of accomplishment.

\begin{abstract}
"We are sad, but with the feeling of accomplishment, right... because we always try to do our best at all times, either when the child is okay, or when they are in a serious condition and at the time of death as well... And with great respect, right. Normally, we allow them to do whatever they want to do: cuddle, bath, change, everything... We feel powerless in the face of the situation but we have to be aware that we did everything possible that moment... Parents see that we are doing everything, you know? The other day I got very happy... some parents came here in the same year that their baby died, to give me a little gift and wish "Merry Christmas". I think this care was very rewarding, and this case touched everyone here. It was nice because a bond was established in a healthy way, you know?" (CSD 5)
\end{abstract}

\section{DISCUSSION}

The difficulty faced by nurses taking care of dying newborns and their families appears to be quite eloquent in the discourses. Emotional involvement is inevitable because these professionals follow the newborn in their daily work shift, from their admission to the unit until the time of their death or discharge.

A study points to the ambivalence between feeling and acting, experienced by health professionals in child care without healing possibilities because the bond that makes them close is the same that makes these professionals suffer when death is near ${ }^{(9)}$.

On the fact that the nurses interviewed have greater difficulty accepting the death of a newborn compared to an adult, the literature shows that any loss is a challenge for people. It requires adaptation and reorganization, modifying the normal course of life. For humans, it is difficult to cope with and facing death, even though it is part of life, especially in the case of a newborn ${ }^{(10)}$.

According to the perception of nurses in the present study, the feeling of impotence by failing to prevent the death of the newborn is highlighted, followed by relief to understand that this event puts an end to their suffering.

The feelings that emerge before death in the neonatal period are complex because they stimulate reflection on human finitude. The death of the other is a reminder of their own death and herein lies the difficulty of people to offer help and affection when they need to say goodbye to others $^{(11-12)}$.

The preparation and the effort of health professional to maintain the life of the baby and the interaction with their families and the need to confront grief at the end of a life that has barely begun, makes this experience even harder to be faced ${ }^{(12)}$.

The discourses also show that nurses are aware of the intense suffering of the families, especially parents. They understand that the family needs to experience the grieving stages and strives to help them go through them as best they can.

The loss of a child is one of the most devastating events that can happen because it involves three different moments: the past of building dreams, frustration and endless suffering of the present and the uncertainty of the future ${ }^{(11)}$.

For the preparation of a healthy grief, some aspects are facilitators, such as when the baby's death is viewed in a real way by his/her family, including goodbye, funeral and performing other rituals. Offering space for listening and reception of feelings also favors the expression of the family, enabling them to outline another meaning for this loss ${ }^{(11)}$. The nurses of this study also used facilitating strategies to support the moment of goodbye between the family and the baby.

The inclusion of palliative care programs in the neonatal period is currently considered an important care strategy when issues related to the promotion of quality care for the infant without possibility of cure are addressed. These programs emphasize the need for care that promote physical comfort as warmth, touch and proper positioning in bed or on the lap of parents, among others.

Physical and emotional benefits are obtained with these initiatives, both for the newborn, reducing the physical symptoms that cause discomfort, and for his/her family, softening the emotional and spiritual suffering ${ }^{(9)}$.

Other research reinforces the importance of having in the NICU, a placeholder for the neonatal palliative care. The cozy atmosphere and the staff prepared to meet the family's needs are important, including that to be transferred to this unit, family members do not feel abandoned by the professionals with whom they have already created a bond ${ }^{(13)}$.

Nurses interviewed seek strategies to cope with loss and dealing with family in these situations, reflecting on the efforts made to maintain the life of the newborn. Accordingly, being faced with the possibility of newborn death in their daily lives is faced with the difficulty of deciding 
the feasibility of treatment for seriously ill patients and nonconformity with death when therapeutic measures do not achieve success ${ }^{(10)}$.

The daily life of the neonatal ICU of nursing professionals is not sufficient to prepare them to deal with the death of a newborn. Feelings of guilt, failure and denial of death emerge, representing difficulty in understanding the transition life and death at this moment ${ }^{(14)}$.

Providing the news of death to the newborn's parents is another moment of great difficulty for the professional who feels the pain of the other and cannot handle it because they are unaware of the limits and needs of caregivers ${ }^{(10)}$.

One of the nurse's participant claims that there is influence of suffering in their professional performance and personal life. Research shows that, as with the family, the death of the child psychologically impacts these professionals, who seek personal means to cope optimally with the child's loss ${ }^{(9)}$.

Illness is one aspect that keeps individuals always connected to the death and its variations. During their education, nurses perceive themselves as being finite and mortal, when they are inserted in the hospital field in his/her academic training process. When they experience the death of the other, they reflect on their own death and of their loved ones ${ }^{(15)}$.

Being resilient and understanding death as a natural part of the life cycle can help nurses to live these situations with less suffering. They often seek help from peers, privately, it's well accepted by professionals that the proposed aid groups or group discussions ${ }^{(16)}$.

Once professionals understand their limitations before death and accept it as a natural event, health practitioners need to reframe their care experience. The ability to help patients and families to cope with the death of the newborn is a task perceived as rewarding and a multidisciplinary work, essential at that moment ${ }^{(11)}$. The discourses point to the feeling of accomplishment shown by the professional, when they realize they did the best for the baby and his/her family.

Studies conducted with parents of children and newborns that died after a period in the ICU and nurses working in neonatal units revealed some of the attitudes of nursing professionals who helped families facing the death of their children, namely, being a sensitive and experienced team, having compassion and encouraging parental involvement in care decisions contribute to a constructive experience ${ }^{(17)}$.
When the professional appears to be insensitive to the suffering of family members, there are conflicts with parents and they do not promote the necessary support, they demonstrate difficulty to address the issues of death, with the family. They also shows their inexperience and inability in the experience of this difficult experience for professionals and especially for families ${ }^{(17)}$.

The care of those in grief requires sophisticated and difficult relationships to be articulated than the apparent simplicity of the models of care. This care involve the need to pay attention to those in grief particularities to guide them in this difficult life situation, helping them to realize that sometimes what could bring comfort is, ironically, what they are avoiding to do, such as talking about their loss ${ }^{(18)}$.

Efforts to share the suffering, pain and powerlessness in the face of loss can make the experience of death of the newborn something less lonely for the professional ${ }^{(18)}$.

The findings of this study reinforce the need to establish a network of support for professionals working in situations of intense suffering, as it happens with the ones working in intensive care units, among others.

\section{FINAL CONSIDERATIONS}

The experience in caring for a dying newborn and his/her family showed it as a very difficult time for the nurse, seeking strategies for dealing with stress, searching how they can externalize it through crying or asking for help from other professionals when they do not feel they can meet the family's needs.

They recognize the dimension of the family suffering, for whom it is much more difficult to experience the death of the newborn, and strives to help them face the moment of death offering a warm atmosphere, using touch, respecting the silence of the family and showing readiness to listen to them. Also emphasizing the importance of establishing a bond of trust with the family.

Despite all sadness and anguish lived, the nurse also experience the feeling of accomplishment, as they understand they did the best possible in the care of the newborn and his/her family.

The development of multidisciplinary groups that meet regularly can be very effective, in order to allow a space for members of the health team to verbalize their feelings and difficulties, minimizing their anxieties.

Another important issue to consider is the need to prepare professionals to deal with situations of grief and death from the beginning of their training and professional education.

\section{RESUMO}

Objetivos: Compreender as experiências vivenciadas por enfermeiros ao cuidar de neonatos que estão morrendo e seus familiares na UTIN; e resgatar as suas percepções sobre a atuação diante do processo de morte e luto. Métodos: Estudo descritivo exploratório, de abordagem qualitativa, desenvolvido com nove enfermeiras da UTIN de um hospital de São Paulo (SP), Brasil. Os dados foram coletados por meio de entrevista semi-estruturada e analisados pela técnica do Discurso de Sujeito Coletivo (DSC). Resultados: Cuidar de neonatos que estão morrendo e suas famílias é muito difícil para as enfermeiras, devido ao intenso envolvimento. Buscam estratégias para lidar com a situação e, diante do óbito do neonato, apesar do sofrimento, manifestam o sentimento de dever cumprido. Considerações finais: Enfrentar a morte e o luto aciona mecanismos que afloram referências de vida, deparando-se com questões dolorosas. Aprender a lidar com essas questões é um desafio diário para os enfermeiros de UTIN.

\section{DESCRITORES}

Morte; Cuidados de Enfermagem; Unidades de Terapia Intensiva Neonatal. 


\section{RESUMEN}

Objetivos: Conocer las experiencias de las enfermeras en el cuidado de los recién nacidos que están muriendo y sus familias en la NICU y redimir sus percepciones acerca de la actuación antes de la muerte y el proceso de duelo. Métodos: Estudio descriptivo exploratorio con abordaje cualitativo, desarrollado con nueve enfermeras en la unidad de cuidados intensivos de un hospital de São Paulo (SP), Brazil. Los datos fueron recolectados a través de entrevistas semi-estructuradas y analizados mediante el Sujeto Colectivo Discurso (CSD). Resultados: El cuidado de los recién nacidos que están muriendo y sus familias es muy difícil para las enfermeras, debido a la intensa participación. Buscar estrategias para hacer frente a la situación y, antes de la muerte del recién nacido, a pesar del sufrimiento, expresó el sentimiento de logro. Consideraciones finales: Frente a la muerte y el dolor desencadena mecanismos que surgen referencias vida, encontrando con problemas dolorosos. Aprender a lidiar con estas preguntas es un reto diario para las enfermeras de la UCIN.

\section{DESCRIPTORES}

Muerte; Atencíon de Enfermeria; Unidades de Cuidado Intensivo Neonatal.

\section{REFERENCES}

1. Stelmak AP. Algoritmos de cuidado de enfermagem fundamentados no método canguru: uma construção participativa [dissertação de mestrado]. [Curitiba]: Universidade Federal do Paraná, Departamento de enfermagem; 2014. $206 f$.

2. Brasil. Ministério da Saúde. Secretaria de Atenção à Saúde. Departamento de Ações Programáticas Estratégicas. Atenção à saúde do recém-nascido: guia para os profissionais de saúde [livro eletrônico]. 2a ed. Brasília: Ministério da Saúde; 2012. [citado 2015 Nov 27]. Disponível em: http://bvsms.saude.gov.br/bvs/publicacoes/atencao_saude_recem_nascido_profissionais_v1.pdf

3. Brasil. Ministério da Saúde. Secretaria de Atenção à Saúde. Departamento de Ações Programáticas Estratégicas. Atenção humanizada ao recém nascido de baixo peso: método canguru [livro eletrônico]. 2a ed. Brasília: Ministério da Saúde; 2011. [citado 2015 Nov 27]. Disponível em: bvsms.saude.gov.br/bvs/publicacoes/Manual_MetodoMaeCanguru.pdf

4. Klock P, Erdmann AL. Caring for newborns in a NICU: dealing with the fragility of living/surviving in the light of complexity. Rev Esc Enferm USP [Internet]. 2012 [cited 2015 Nov 27]; 46(1): 45-51. Available: http://dx.doi.org/10.1590/S0080-62342012000100006

5. Poles K, Bousso RS. Dignified death for children: concept analysis. Rev Esc Enferm USP [Internet]. 2009 [cited 2001 June 21];43(1):215-22. Available from: http://www.scielo.br/pdf/reeusp/v43n1/en_28.pdf

6. Baldissarella L, Dell'Aglio DD. No limite entre a vida e a morte um estudo de caso sobre a relação pais/bebê em uma UTI Neonatal. Estilos Clín [Internet]. 2009 [citado 2015 Nov 27]; 14(26): 68-89. Disponível em: http://dx.doi.org/10.11606/issn.1981-1624. v14i26p68-89

7. Lefevre F, Lefevre AM. O discurso do sujeito coletivo: um novo enfoque em pesquisa qualitativa. 2a ed. Caxias do Sul: EDUCS; 2005. (Desdobramentos).

8. Lefevre F, Lefevre AM, Marques MC. Discurso do sujeito coletivo, complexidade e auto-organização. Ciênc Saúde Coletiva [Internet]. 2009[citado 2015 Nov 27]; 14(4): 1193-204. Disponível em: http://dx.doi.org/10.1590/S1413-81232009000400025.

9. Silva AF, Issi HB, Motta MG, Botene DZ. Critical care nursing professionals' perceptions about the death of the newborn. Rev Gaúcha Enferm [Internet]. 2015[cited 2015 Nov 27]; 36(2): 56-62. Disponível em: http://dx.doi.org/10.1590/1983-1447.2015.02.46299

10. Silva PS, Valença NC, Germano MR. Percepções dos profissionais de enfermagem intensiva frente a morte do recém-nascido. Rev Bras Enferm [Internet]. 2010[citado 2015 Nov 27]; 63(2) 238-42. Disponível em: http://dx.doi.org/10.1590/S0034-71672010000200011

11. Oishi KL. O Jardim de Julia: a vivência de uma mãe durante o luto. Psicol Teor Pesqui [Internet]. 2014 [citado 2015 Nov 27]; 30(1): 5-11. Disponível em: https://revistaptp.unb.br/index.php/ptp/article/view/561

12. Silva LC , Valença CN , Germano RM. Estudo fenomenológico sobre a vivência da morte em uma unidade de terapia intensiva neonatal. Rev Bras Enferm [Internet]. 2010 [citado 2015 Nov 27]; 63(5): 770-4. Disponível em: http://dx.doi.org/10.1590/S003471672010000500012

13. Kain V. Exploring the barriers to palliative care practice in neonatal nursing: A focus group study. Neonatal, Paediatric and Child Health Nursing. 2011; 14(1): 9-14.

14. Cardoso DH, Muniz RM, Schwartz E, Arrieira IC. Cuidados paliativos na assistência hospitalar: a vivência de uma equipe multiprofissional. Texto Contexto Enferm [Internet]. 2013 [citado 2015 Nov 27]; 22(4): 1134-41. Disponivel em: http://dx.doi.org/10.1590/ S0104-07072013000400032

15. Kempfer SS, Carraro TE. Temporalidade: o existir e a perspectiva da finitude para o ser-acadêmico-de-enfermagem ao experienciar a morte. Texto \& Contexto Enferm [Internet]. 2014[citado 2015 Nov 27]; 23(3): 728-34. Disponível em: http://www.scielo.br/ pdf/tce/v23n3/pt_0104-0707-tce-23-03-00728.pdf

16. Bloomer MJ, O'Connor M, Copnell B, Endacott R. Nursing care for the families of the dying child/infant in paediatric and neonatal ICU: nurses' emotional talk and sources of discomfort. A mixed methods study. Aust Crit Care. 2015;28(2):87-92.

17. Brooten D, Youngblut JM, Seagrave L, Caicedo C, Hawthorne D, Hidalgo I, Roche R. Parent's perceptions of health care providers actions around child ICU death: what helped, what did not. Am J Hosp Palliat Care. 2013; 30(1):40-9.

18. Bousso RS. The complexity and simplicity of the experience of grieving. Acta Paul Enferm [Internet]. 2011[cited 2015 Nov 27]; 24(3): VII-VIII. Available from: http://dx.doi.org/10.1590/S0103-21002011000300001 